\title{
PENGEMBANGAN MODEL FASILITASI BELAJAR DALAM MEMBERDAYAKAN MASYARAKAT PELAKU USAHA KECIL
}

\section{Abstrak}

Penelitian ini mengkaji tentang upaya pemberdayaan masyarakat pelaku usaha kecil yang berada pada sentra usaha kerajinan Cibeusi di Kabupaten Sumedang, dengan fokus permasalahan bagaimana model fasilitasi belajar yang dapat memberdayakan kelompok pelaku usaha kecil dalam mengembangkan kemandirian usaha produktifnya?. Tujuan penelitian ini adalah mengembangkan program pemberdayaan pada masyarakat pelaku usaha kecil melalui model fasilitasi belajar. Model fasilitasi belajar dirumuskan berdasarkan dukungan teoritis yang mengkaji tentang: konsep pembelajaran, pemberdayaan dan usaha kecil. Disain penelitian menggunakan Research and Development, dengan metode studi kasus, deskriptif, dan uji eksperimen. Analisis data menggunakan analisis kualitatif dan kuantitatif, dengan sampel penelitian 30 orang diambil secara purposif.

Temuan penelitian ini: (1) secara alamiah dalam menjalankan usahanya anggota kelompok dihadapkan pada keterbatasan pengetahuan, sikap dan keterampilan, sehingga mereka membutuhkan fasilitasi belajar, (3) kegiatan model fasilitasi belajar adalah proses perencanaan, pengorganisasian, pelaksanaan dan penilaian pembelajaran, (4) uji coba model menunjukan hasil efektif, dengan indikator: pertama adanya keterlibatan aktif anggota kelompok. Kedua, data nilai pre-test dan post-tes menunjukkan angka signifikan. Kesimpulan penelitian adalah bahwa model fasilitasi belajar dipandang efektif dan berimplikasi teoritis dan praktis.

Kata Kunci: Fasilitasi Belajar, Pemberdayaan, Produktifitas, Usaha Kecil.

*) Dr. Asep Saepudin, M.Pd., Dosen STMIK Mardira Indonesia dan Pemerhati Pengembangan Usaha Kecil di Indonesia. 


\section{PENDAHULUAN}

\section{A. Latar Belakang}

Komitmen awal tujuan berdirinya negara Republik Indonesia sebagaimana tertuang dalam alinea keempat pembukaan Undangundang Dasar 1945 diantaranya adalah kesejahteraan bagi seluruh bangsa Indonesia. Oleh karena itu, dalam proses pembangunan nasional setiap warga negara Indonesia harus merasa terjamin akan persamaan hak dan kewajibannya dalam segala aspek kehidupan. Kenyataan menunjukkan bahwa kondisi masyarakat saat ini dihadapkan dengan sejumlah permasalahan yang sangat rumit. Rendahnya kualitas sumber daya manusia, rendahnya pendapatan masyarakat, tingkat kemiskinan yang tinggi, bertambahnya jumlah pengangguran, dan sejumlah permasalahan lainnya yang perlu segera ditanggulangi melalui berbagai program pembangunan, diantaranya pembangunan ekonomi kerakyatan. Revrisond yang dikutif Moh. Jafar Hafsah, (2000:31) memaknai ekonomi kerakyatan sebagai suatu situasi perekonomian dimana berbagai kegiatan ekonomi diselenggarakan dengan melibatkan partisipasi semua anggota masyarakat, hasilnya dinikmati oleh seluruh anggota masyarakat, sementara penyelenggaraan kegiatan ekonomi itu pun berada di bawah pengendalian atau pengawasan anggota-anggota masyarakat dan pemerintah.

Salah satu bentuk penyelenggaran ekonomi kerakyatan adalah pemberdayaan usaha kecil, sebagai lembaga usaha rakyat yang telah lama tumbuh sumbur secara alamiah bahkan turun temurun. Upaya mengembangkan kelompok usaha kecil dipandang tepat dan cukup beralasan pada saat situasi perekonomian Indonesia diarahkan pada penumbuhan ekonomi kerakyatan. Beberapa alasan perlunya dikembangkan usaha kecil di Indonesia, diantaranya, pertama usaha kecil menyumbang sangat banyak kesempatan kerja secara potensial, yakni berperan sebagai salah satu sumber pendapatan atau pertumbuhan produk domestik bruto (PDB) dan ekspor non-migas. Kedua, usaha kecil diyakini 
mempunyai peran yang besar tidak saja dalam penyediaan berbagai barang dan jasa untuk kebutuhan lokal maupun ekspor, penyerapan tenaga kerja dan kesempatan usaha, tetapi juga karena kemampuannya sebagai kegiatan ekonomi alternatif. Ketiga, sebagai bagian dari dinamikanya, Usaha Kecil sering mencapai peningkatan produktivitasnya melalui investasi dan perubahan teknologi. Keempat, adalah karena sering diyakini bahwa usaha kecil memiliki keunggulan dalam hal fleksibilitas ketimbang usaha besar.

Atas dasar alas an tersebut di atas, pemerintah selama ini secara berkelanjutan melakukan pemberdayaan bagi Usaha Mikro Kecil dan Menengah (UMKM)", yang disertai dengan penganggaran dana dalam APBN yang dialokasikan kepada APBD bekerjasama dengan lembaga-lembaga keuangan, untuk menentukan regulasi kredit bantuan permodalan dengan bunga murah dan akses cepat bagi pelaku usaha kecil di seluruh Indonesia yang jumlahnya mencapai 42 juta unit (Tulus Tambunan, 2003). Walaupun kebijakan dan realisasi pemberdayaan usaha kecil telah lama dijalankan, namun belum sepenuhnya mencapai target yang diharapkan. Kenyataannya menunjukan bahwa secara umum pelaku usaha kecil saat ini masih menghadapi berbagai kendala dalam pengembangan usahanya terutama berkenaan dengan: (a) permodalan usaha, (b) pemasaran produk, (c) rendahnya kemampuan sumber daya manusia, dan (d) akses teknologi.

Untuk menanggulangi berbagai kendala yang dihadapi pelaku usaha kecil sehingga terjadinya peningkatan produktivitas dan terpenuhinya kebutuhan belajar bagi anggota kelompok usaha kecil diperlukan intervensi lain yang diorientasikan untuk memfasilitasi belajar mereka dalam meningkatkan pengetahuan, sikap dan keterampilan bagi kelancaran usahanya. Untuk itu, perlu upaya penelitian dan pengembangan program pembelajaran bagi pemberdayaan kelompok usaha kecil dalam meningkatkan kemandirian produktivitas usahanya. 


\section{B. Fokus dan Masalah Penelitian}

Penelitian ini diarahkan untuk mengembangkan model fasilitasi belajar bagi pemberdayaan masyarakat pelaku usaha kecil berdasarkan landasan pendidikan luar sekolah. Untuk itu, permasalahan penelitian ini adalah: Bagaimana model fasilitasi belajar yang dapat memberdayakan kelompok usaha kecil untuk mengembangkan kemandirian usaha produktifnya?

Berdasarkan rumusan permasalahan penelitian di atas, untuk mengarahkan pengumpulan data, maka permasalahan penelitian dapat dijabarkan kedalam beberapa pertanyaan penelitian berikut: (1) Bagaimana gambaran umum anggota dan profil perusahaan yang dikelola kelompok pelaku usaha kecil?, (2) Bagaimana model program fasilitasi belajar untuk meningkatkan kemampuan anggota kelompok pelaku usaha kecil dalam upaya mengembangkan kemandirian usaha produktif yang sedang dilakukannya?, (3) Bagaimana efektivitas model fasilitasi belajar yang ditandai dengan peningkatan kemampuan pengetahuan, perubahan sikap dan keterampilan anggota kelompok pelaku usaha kecil dalam mengembangkan kemandirian usaha produktif yang sedang dilakukannya?

\section{KAJIAN LITERATUR}

\section{A. Konsep Fasilitasi Belajar \\ 1. Batasan Fasilitasi Belajar}

Istilah "fasilitasi" atau memfasilitasi berasal dari kata bahasa Inggris "Facilitation" yang akar katanya berasal dari bahasa Latin "facilis" yang mempunyai arti "membuat sesuatu menjadi mudah" (Carell, 2004:1). Dalam Oxford-English Dictionary (2000), facilitation disebutkan :"to render easier, to promote, to help forward; to free from difficulties and obstacles".

Dalam pengertian yang lebih lengkap, kelompok pengembang FSDP atau Facilitation Skills Development Process (2001:1) 
menjelaskan istilah fasilitasi sebagai berikut: Facilitation means making something easier. The facilitation of groups involves assisting or guiding people in the process of change so that they achieve their desired goals or outcomes in a non-stressful manner. Berdasarkan pengertian tersebut di atas, fasilitasi dapat diartikan sebagai upaya untuk membuat sesuatu lebih mudah. Termasuk didalam kegiatan fasilitasi adalah membantu atau membimbing orang-orang dalam proses perubahan sehingga mencapai tujuan atau hasil tertentu yang diinginkannya dalam suasana menyenangkan".

Sedangkan Grove (2004:2) mengartikan konsep fasilitasi adalah: "the art of leading people through processes toward agreed-upon outcomes in ways that elicit participation, ownership, and creativity from all involved. Pengertian di atas memaknai fasilitasi sebagai seni mengarahkan orang-orang melalui proses tertentu sehingga mencapai hasil sebagaimana yang ditetapkan sebelumnya dengan cara menumbuhkan partisipasif, rasa memiliki dan kreatifitas dari semua pihak yang terlibat didalamnya. Oleh karena itu, "facilitation" (fasilitasi) merupakan paduan dari metoda dan seni dalam proses "mempermudah" mencapai tujuan tertentu.

Jika belajar didefinisikan sebagai proses perubahan, sebagaimana diungkapkan Gagne dan Travers dalam H.D.Sudjana (2000b:58) bahwa: belajar sebagai suatu perubahan disposisi atau kecakapan baru yang terjadi karena adanya usaha yang disengaja, maka "fasilitasi belajar" dapat diartikan sebagai metode dan seni dalam upaya membantu atau mempermudah kegiatan belajar bagi individu dalam kelompok melalui proses bimbingan (pendampingan) sehingga terjadi perubahan kemampuan atau kecakapan pada diri individu dalam kelompok tersebut baik pengetahuan (cognitif), sikap (afektif), maupun keterampilannya (psikomor) sehingga mencapai tujuan tertentu yang diharapkan. Dalam bahasa lain fasilitasi belajar adalah keterampilan membantu terjadinya 
pertukaran informasi yang efisien dan efektif sehingga terjadi proses belajar yang optimal.

Pentingnya dikembangkan konsep fasilitasi belajar, didasarkan pada beberapa asumsi diantaranya: pertama, setiap individu memiliki potensi dasar yang dapat dikembangkan melalui proses belajar. Menurut Sumaatmadja (1996:42) potensi dasar individu yang dapat dikembangkan melalui proses belajar adalah: rasa ingin tahu (sense of curiousity), rasa tertarik (sense of interest), keinginan untuk mengetahui kenyataan (sense of reality), dorongan untuk menemukan diri sendiri (sense of inquiry), dan keinginan untuk menemukan (sense of discovery). Potensi tersebut akan berkembang jika ada wahana, rangsangan, bimbingan, dan suasana yang kondusif sebagai faslitasi untuk tumbuhnya proses belajar. Fasilitasi belajar dalam interaksi individu dalam kelompok merupakan dorongan untuk pengembangan potensi diri dan perkembangan jiwa raga, sehingga mereka tetap survive dan memiliki daya tahan terhadap lingkungan hidupnya. Kedua, dalam setiap proses belajar setiap individu selalu dihadapkan pada berbagai masalah dalam belajarnya mencapai tujuan yang diharapkan.

\section{Prosedur Fasilitasi Belajar}

Kelompok kerja Thiagi (1999:2) mengembangkan model prosedur fasilitasi belajar yang efektif, yakni:

a. Identifikasi aspek-aspek fasilitasi, yang berkenaan dengan: tujuan, langkah yang tepat dan cepat, pola interaksi kerjasama, hasil yang diharapkan, perhatian individu, dan evaluasi. Dengan ditetapkannya aspek-aspek tersebut, akan menghindari tingkat penyimpangan dalam proses fasilitasi.

b. Identifikasi kebutuhan belajar anggota kelompok (warga belajar). Sebelum merencanakan suatu kegiatan dalam kelompok, fasilitator harus mengumpulkan informasi 
tentang kebutuhan anggota kelompok berkenaan dengan fasilitasi belajar. Sumber informasi terbaik adalah informasi dari sampel (beberapa) anggota kelompok. Strategi yang terbaik untuk mengumpulkan informasi tersebut melalui wawancara.

c. Buat disain fasilitasi belajar berdasarkan kebutuhan belajar anggota kelompok. Dalam merancang suatu simulasi kegiatan atau kegiatan lain yang melibatkan anggota yang ada, fasilitator memadukan pemahamannya dengan pilihan kebutuhan anggota dalam kegiatan kelompok.

d. Lakukan kegiatan dalam kelompok berdasarkan desain yang dianggap telah sesuai, fasilitator dan kelompok mulai melakukan kegiatan secara bersama-sama penuh kepercayaan. Buatkan suatu ikhtisar (ringkasan) proses dan produk yang dilakukan anggota kelompok.

e. Membuat modifikasi kegiatan yang sedang berjalan. Semua peserta atau anggota kelompok membahas aktivitas, secara terus-menerus memonitor kegiatan pada setiap kebutuhanya, sehingga kebutuhan fasilitasi belajar tidak bertentangan dengan aktivitas kelompok.

f. Mewawancarai semua atau sebagian anggota secara spontan. Hal ini dilakukan untuk mengumpulkan informasi tentang persepsi mereka dari pada setiap aspeknya. Kegiatan ini bisa dilakukan dalam beberapa menit seperti mengajukan pertanyaan.

\section{Prinsip-prinsip Fasilitasi Belajar}

Fasilitasi belajar sebagai sebuah proses pembelajaran, memiliki prinsip-prinsip belajar sebagaimaan diungkapkan Carell (2004:2) sebagai berikut: Pertama, kesamaan derajat, yaitu setiap anggota kelompok atau warga belajar mempunyai sesuatu yang dapat disumbangkan pada peserta belajar dan perlu diberikan kesempatan yang adil untuk melakukan hal itu. Kedua, kerjasama, yaitu fasilitator dan para peserta bekerjasama untuk mencapai tujuan bersama mereka. Orang 
mungkin akan mengatakan bahwa kepemimpinan adalah sesuatu yang dilakukan oleh seseorang terhadap sebuah kelompok. Sedangkan fasilitasi/memandu adalah sesuatu yang dilakukan oleh seseorang bersama dengan sebuah kelompok. Ketiga, kejujuran, yaitu fasilitator mewakili secara jujur nilainilai dirinya sendiri, perasaan, keprihatinan dan prioritas dalam bekerja bersama seluruh peserta pelatihan, dan fasilitator seharusnya menentukan suasana bagi suatu harapan akan kejujuran dari seluruh peserta. Keempat, tanggung jawab, yaitu setiap orang bertanggungjawab atas kehidupannya masingmasing, pengalaman-pengalaman dan tingkah lakunya sendiri. Hal ini mencakup pula pada tanggungjawab atas partisipasi seseorang di dalam sebuah pertemuan atau pelatihan.

\section{B. Konsep Pemberdayaan}

\section{Batasan Pemberdayaan}

Pemberdayaan merupakan paket yang tidak bisa dipisahkan dari tujuan Community Development. Dalam konteks pengembangan komunitas, masyarakat atau komunitas sasaran ditempatkan sebagai pihak yang akan menerima kekuatan (daya/power) atau sebagai pihak yang diberdayakan, dan bersamaan dengan itu sebuah program atau proyek atau pelaku pelaksana program pendampingan, disebut sebagai si pemberdaya.

Menurut Merriam Webster dan Oxford-English Dictionary (2000), kata empower mengandung dua arti. Pengertian pertama adalah to give power or authority to. Pengertian kedua mengadung arti to give ability or enable. Priyono (1996:3) memberikan penafsiran terhadap kedua pengertian tersebut. Pengertian pertama diartikan sebagai memberi kekuasaan, mengalihkan kekuatan, atau mendelegasikan otoritas kepada pihak lain. Sedangkan pengertian kedua diartikan sebagai 
upaya untuk memberi kemampuan atau keberdayaan. Jamasy (2004) mengungkapkan arti pemberdayaan itu tidak hanya sekedar memberi kekuasaan itu terhadap pihak tersebut. la memilih kata empowering menjadi power yang berarti kontrol, kekuasaan, dominion, dan awalan em yang berarti mengenakan atau menutupi dengan.

\section{Langkah-Langkah Pemberdayaan}

Kaitannya dengan langkah-langkah pemberdayan, Aileen Mitchell Stewart (1994:73-86) menjelaskan delapan butir-butir pemberdayaan diantaranya:

a). Envision (mengembangkan visi bersama), dalam arti sebelum kegiatan pemberdayaan dilakukan, terlebih dahulu tetapkan suatu visi bersama yang jelas, yang menekankan prioritas, tujuan-tujuan bersama, dan kerjasama (bukan kompetisi). Hal ini perlu dilakukan sehingga tiap orang memiliki gambaran yang jelas tentang apa yang dikehendaki dan mengapa. Jika setiap orang jelas tentang tujuan kegiatan, maka sebagian besar kegiatan akan terkoordinasi dengan sendirinya. Selanjutnya sarana untuk mencapai tujuan dapat diserahkan kepada masing-masing individu, asalkan tolok ukurnya ditetapkan.

b). Educate (mendidik), dalam arti bahwa pemberdayaan sejati menuntut individu agar dapat mengambil keputusan secara mandiri, yang mungkin dapat beraneka ragam tergantung pada keadaan, untuk itu di butuhkan pendidikan, bukan hanya pelatihan. Sangat besar perbedaan pendidikan dan pelatihan. Pelatihan bertujuan menstandarkan perilaku, untuk menjamin bahwa individu akan berperilaku secara konsisten dan dapat diandalkan dalam keadaan tertentu yang telah diperkirakan sebelumnya. Sedangkan melalui pendidikan individu akan mengerti mengapa dan apa-nya jika mereka harus mengambil keputusan yang baik. Individu harus berpikir sendiri dan harus mengambil keputusan sendiri tentang apa yang harus dikerjakan. 
c). Eliminate (menyingkirkan rintangan-rintangan), dalam arti bahwa pihak yang memberdayakan perlu berusaha menyingkirkan segala rintangan terhadap permberdayaan. Pertama-tama, la perlu memastikan bahwa segala sistem dan prosedur sejalan dengan tujuan kegiatan dan dengan pemberdayan sebagai proses untuk mencapai tujuantujuan itu. jauhkan segala macam halangan (entah itu orang, prosedur adminsitratif, ataupun hal-hal teknis).

d). Express (mengungkapkan), dalam arti kesiapan untuk mengungkapkan atau menjelaskan baik dari pelaku pemberdayaan maupun dari individu pserta pemberdayan. Pelaku harus siap menjelaskan bukan hanya tentang arti pemberdayaan, tetapi juga manfaat-manfaat yang dapat didatangkannya, baik bagi mereka secara pribadi maupun bagi kelompok/organisasi secara keseluruhan. Sebaliknya individu sasaran pemberdayan juga perlu dapat mengungkapkan pandangan-pandangan atau pendapat mereka kepada pihak yang melakukan pemberdayaan. Mereka perlu merasa bebas mengungkapkan, gagasan, pendapat, ketakutan dan keprihatinan mereka dalam suasana cemoohan dan kritik yang bersifat menyensor.

e). Enthuse (Menyemangati), dalam arti pelaku pemberdayaan harus dapat menciptakan kegairahan dan semangat akan program pemberdayaan itu. Jika pelaku pemberdayaan stengah-setengah atau tidak bersemangat terhadap pemberdayaan jangan harap orang lain pun akan semangat. Pelaku pemberdayaan harus tahu dimana kegembiraan itu dapat ditemukan dan kemudian disampaikan kepada idividu yang diberdayakan

f). Equip (melengkapi), dalam arti bahwa suatu cara yang sangat efektif untuk memberdayakan adalah membiarkan mereka mengatur anggaran sendiri, Jika pelaku usaha tidak siap menyerahkan sumber-sumber biaya dan tanggung jawab finansial yang melekat pada suatu kegiatan, pemberdayaan tidak dapat terjadi. 
g). Evaluate (menilai), dalam arti jika suatu pemberdayaan telah berjalan, pentinglah mematau perkembangnnya dan menilai hasilnya. Pemberdayan pada pokoknya merupakan proses, bukan peristiwa, maka pemantauan dan penilaian harus dilakukan terus menerus dan menjadi ciri manajemen pelaku pemberdayaan selanjutnya. Hal-hal yang perlu dievaluasi diantaranya mempertimbangkan apakah sasaran-sasaran dari standar-standar sudah: ditetapkan, dipenuhi, dan dicermati. Selain itu perlu menilai seberapa efektif sasaran-sasaran dan standar-standar itu untuk mencapai kseluruhan tujuan.

h). Expect (mengharapkan), dalam arti bahawa proses pemberdayaan akan dihadapkan pada dua hal, yakni permasalahan dan keberhasilan. Pelaku pemberdayaan perlu mengharapkan timbulnya permasalahan (bahkan membuat rencana untuk menghadapinya) agar kita siap dan tidak dikacaukan apabila permasalahan timbul. Selanjutnya pelaku pemberdayaan perlu mengharapkan keberhasilan dari proses pemberdayaan Keyakinan akan mencapai keberhasilan hal penting dalam pemberdayaan. Dengan menanamkan keoptimisan untuk berhasil, maka pelaku dan sasaran pemberdayaan akan mampu mengatasi permasalahan yang muncul. Oleh sabab itu, bersiaplah menghadapi masalah-masalah, tetapi juga harapkanlah keberasilan. Dengan demikian harapan kita menjadi ramalan yang sungguh-sungguh terjadi.

\section{Konsep Usaha Kecil}

\section{Batasan Usaha Kecil}

Menurut Undang-undang No.9 tahun 1995 tentang usaha kecil dilihat dari segi keuangan dan modal yang dimilikinya, yaitu: memiliki kekayaan bersih paling banyak Rp. 200 juta (tidak termasuk tanah dan bangunan tempat usaha), atau memiliki hasil penjualan paling banyak Rp. 1 milyar/tahun, bersifat Independen, tidak terafiliasi dengan usaha menengah-besar, boleh berbadan hukum, boleh tidak. 
Dalam perkembangan berikutnya, batasan usaha kecil dikembangkan oleh banyak organisasi, sehingga batasan usaha kecil sangat bervariasi antara satu organisasi dengan organisasi lainnya. Cakupan definsi usaha kecil ada yang membatasinya pada aspek penyerapan tenaga kerja, aset modal yang dimiliki, dan pengelompokan perusahaan ditinjau dari gugus perusahaannya. Tabel berikut, akan menggambarkan batasan/kriteria usaha kecil dan menengah menurut beberapa organisasi.

\section{Tabel 1:Batasan/Kriteria Usaha Kecil dan Menengah Menurut Beberapa Organisasi}

\begin{tabular}{|c|c|c|}
\hline Organisesi & Jenis Usaha & Keteranges Kritteria \\
\hline \multirow{3}{*}{$\begin{array}{l}\text { Badsn Pusst } \\
\text { St=tictik[BPs] }\end{array}$} & Uzsha Mkro & $\begin{array}{l}\text { Pokeria < } 5 \text { orong tormsedk tensga } \\
\text { kelusrga yang tidak dbavar }\end{array}$ \\
\hline & Uasha Keci & Dokerja 5-10 orzeng \\
\hline & Uksha morengah & Dekerja $20-90$ orang \\
\hline \multirow{2}{*}{$\begin{array}{l}\text { Menneg Koperaci \& } \\
\text { PKM }\end{array}$} & Ursha keci [UUNo. 0/1005] & $\begin{array}{l}\text { Aset }<\text { Rp. } 200 \text { uta diusr tansh don } \\
\text { barounan Omact tahuran }<\text { fop. } 1 \\
\text { Milyar }\end{array}$ \\
\hline & $\begin{array}{l}\text { Usaha Merengsh (Inpres } \\
10 / 1000)\end{array}$ & Asct pp. 200 - pp. $10 \mathrm{Mly}$ am \\
\hline \multirow{3}{*}{ Bank Indonesia } & $\begin{array}{l}\text { Uksha Mikro (SK. Dir al No. } \\
31 \text { he4kEPJoIR tol } 5 \text { Mai 1998) }\end{array}$ & 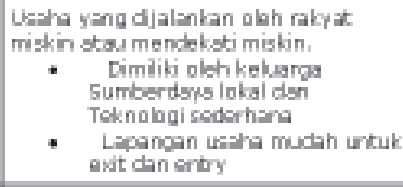 \\
\hline & Ussha Kedi [UU No, 9/1995) & $\begin{array}{l}\text { Aset }<\text { Rp. } 200 \text { uta diusr tansh don } \\
\text { banounan: Omast tahuran < Pp. } 1 \\
\text { Miyar }\end{array}$ \\
\hline & $\begin{array}{l}\text { Wenorgah (5K Dir B1 No, } \\
30 / 45 \text { Dir, } 2 \text { tal S Januan } \\
1997 \text { ) }\end{array}$ & 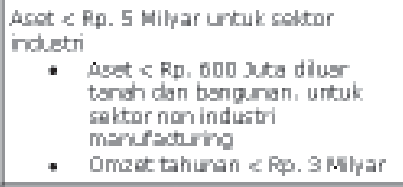 \\
\hline Bank Dunia & Ukatha Mkro Kedl-Mensrgah & $\begin{array}{l}\text { Pekeria < } 20 \text { Crang } \\
\text { * Pokerja 20-150 crang } \\
\text { * Aset }<\text { US\$, 500 ribu diuar } \\
\text { tandi dan bangman }\end{array}$ \\
\hline
\end{tabular}

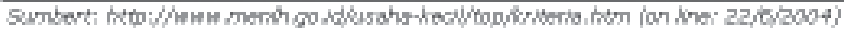




\section{Kelompok Usaha Kecil sebagai Kelompok Belajar}

Kelompok usaha kecil merupakan kelompok belajar dalam upaya memenuhi kebutuhan belajarnya bagi peningkatan pengetahuan dan keterampilan serta perubahan sikap dalam melakukan usaha kelompok menuju ke arah yang lebih baik, peningkatan efisiensi usaha kelompok, peningkatan produktifitas dan pendapatan serta kesejahteraan. Kelompok usaha kecil adalah kumpulan masyarakat yang bersifat nonformal memiliki pandangan dan kepentingan yang sama untuk mencapai tujuan bersama dimana hubungan satu sama lain sesama anggota bersifat luwes, wajar dan kekeluargaan. melakukan kegiatan ekonomi Kelompok usaha kecil sebagai wahana proses belajar, wahana fasilitas pelayanan sarana produksi, dan sebagai wahana fasilitas pengaturan, perlu dibina dan dikembangkan kemampuannya.

Dalam Peraturan Pemerintah No. 73 tahun 1991, terutama pasal 14-19 dijelaskan bahwa bentuk satuan pendidikan luar sekolah yakni: kursus, kelompok belajar, dan satuan pendidikan lainnya dalam bentuk kelompok bermain, penitipan anak, dan satuan pendidikan sejenis yang ditetapkan Menteri. Kaitannya dengan kelompok belajar, secara khsusus dalam peraturan tersebut dijelaskan bahwa kelompok belajar adalah satuan pendidikan luar sekolah yang terdiri atas sekumpulan yang saling membelajarkan pengalaman dan kemampuan dalam rangka meningkatkan mutu dan taraf kehidupan.

Selanjutnya pada pasal 17 dinyatakan bahwa kelompok belajar diselenggarakan bagi sekumpulan warga belajar dengan saling membelajarkan untuk mengembangkan diri, bekerja/atau melanjutkan ke tingkat/atau jenjang pendidikan yang lebih tinggi. Dengan demikian, kelompok usaha kecil merupakan kelompok belajar bagi masyarakat pengrajin yang setara dengan kelompok belajar lainnya, seperti: kelompen capir, kelompok belajar usaha, kelompok belajar Paket A dan B, untuk memudahkan saling membelajarkan bagi peningkatan 
pengetahuan dan keterampilan usaha yang mendukung terhadap peningkatan produktivitas.

\section{PROSEDUR PENELITIAN}

Berdasarkan fokus permasalahan dan tujuan penelitian, maka disain penelitian yang digunakan adalah disain research and development (Borg dan Gall, 1979:624) dengan terlebih dahulu melakukan beberapa modifikasi. Penelitian (research) dan pengembangan (develop) merupakan rangkaian penelitian yang dilakukan secara siklus, dimana langkah yang dilakukan selalu berdasar kepada langkah sebelumnya. Metode penelitian pengembangan dianggap tepat untuk digunakan dalam penelitian ini, karena tujuan penelitian selain menemukan model implementasi fasilitasi belajar bagi masyarakat pelaku usaha kecil, juga mengembangkan model pembelajaran baru yang lebih efektif yang sesuai dengan kondisi dan kebutuhan nyata masyarakat pelaku usaha kecil.

Secara operasional penelitian ini dilakukan dalam tujuh langkah yaitu: (1) studi eksploratis, (2) studi pustaka, (3) penyusunan model konseptual, (4) verifikasi model, (5) implementasi model, (6) analisis dan revisi model, (7) model akhir (hasil implementasi). Pendekatan dan anlalisis yang digunakan adalah pendekatan dan analisis kualitatif dan kuantitatif. Pada pendekatan kualitatif proses pengumpulan dan pengolahan data menekankan peran peneliti sebagai instrumen utama (key instrument) melalui pengamatan dan wawancara mendalam. Pada pendekatan kuantitatif dilakukan proses pengujian melalui eksperimen menggunakan the one-group pretest-posttest design", tanpa kelompok pembanding (Millan \& Schumacher, 2001:331) dan Jack R. Fraenkel (1993:245). 


\section{KESIMPULAN DAN SARAN}

\section{A. Kesimpulan}

\section{Gambaran Umum Anggota dan Profil Pelaku Usaha Kecil}

Pertama, Secara alamiah anggota kelompok pelaku usaha kecil telah memiliki kemampuan pengetahuan, sikap dan keterampilan dalam menjalankan kegiatan usahanya, yang diperolehnya secara indigenous (alamiah) melalui proses pewarisan dari generasi ke generasi. Kedua, Dalam perkembangan kemudian anggota pelaku usaha kecil dihadapkan pada berbagai kendala sekaligus masalah bagi keberlangsungan usahanya. Kendala tersebut secara umum berkenaan dengan upaya penambahan modal usaha dan pemasaran hasil produksi. Ketiga, Berdasarkan analisa terhadap data hasil penelitian, ditemukan bahwa permasalahan yang sesungguhnya adalah keterbatasan kemampuan pengetahuan, sikap dan keterampilan yang mereka miliki, sehingga mereka membutuhkan bantuan atau fasilitasi belajar dalam upaya menghilangkan kesenjangan (gap) antara kemampuan yang dimilikinya dengan kemampuan yang diharapkan.

\section{Pengembangan Model Fasilitasi Belajar}

Pertama, Pengembangan model konseptual dalam bentuk langkah-langkah pembelajaran yang kemudian disebut komponen model yakni (1) perencanaan, (2) pengorganisasian, (3) pelaksanaan dan (4) penilaian terhadap kegiatan belajar penguasaan penggunaan internet dan pembuatan proposal pengajuan kredit bantuan modal usaha. Kedua, model konseptual fasilitasi belajar yang dirumuskan divalidasi kelayakannya melalui teknik: analisa kualitas model, penilaian para ahli (expert), dan uji coba lapangan terbatas. Ketiga, $\mathrm{Uji}$ coba model melalui dua tahap uji coba (implementasi). Indikator yang menunjukan efektifitas model diukur dari: (1) keterlibatan aktif antara anggota kelompok dengan fasilitator, (2) 
meningkatnya partisipasi anggota kelompok dalam kegiatan pembelajaran dalam upaya memenuhi kebutuhan belajarnya, (3) adanya peningkatan kemampuan peserta belajar setelah mengikuti kegiatan pembelajaran, yang diukur melalui penilaian terhadap efektifitas model.

\section{Efektivitas Model Fasilitasi Belajar}

Penilaian terhadap efektifitas model dilakukan secara: (a) deskriptif melalui pengamatan, wawancara dan angket serta (b) secara tes (pre-test dan post-test). Hasil analisa data menunjukan bahwa terdapat peningkatan kemampuan pengetahuan, sikap dan keterampilan anggota kelompok pelaku usaha kecil dalam mengembangkan kemandirian usaha produktifnya, sebagiman tabel berikut:

\section{Tabel 2:}

Data Pemeriksaan Hasil Pengujian Perbedaan

\begin{tabular}{|c|c|c|c|c|c|c|}
\hline Variabel & Natuji & $\begin{array}{c}\text { Kogiotan } \\
\text { Pexthilajaran }\end{array}$ & Ansol & 24nest & a & Kesiemprian \\
\hline \multirow{2}{*}{ Pungatoruan } & \multirow{2}{*}{ U) $t$} & $\begin{array}{c}\text { ASmbuston E-mal } 81 \\
\text { Whatenta }\end{array}$ & 7,15296 & 2,2010 & $9 \%$ & 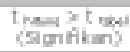 \\
\hline & & $\begin{array}{l}\text { Permbustan Propo- } \\
\text { sal wredtustie }\end{array}$ & 8,93454 & 2,1096 & $5 \%$ & 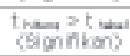 \\
\hline \multirow{2}{*}{ Skoo } & \multirow{2}{*}{$\begin{array}{l}\text { Wiloowon } \\
\text { Moch Pairs } \\
\text { Test (z) }\end{array}$} & $\begin{array}{c}\text { Pernbuston ofmal s } \\
\text { wiobste }\end{array}$ & $-3,0094$ & $-1,96$ & $5 \%$ & $\begin{array}{l}z_{\text {maginians }} \\
\text { csiguis }\end{array}$ \\
\hline & & $\begin{array}{l}\text { Perrbuikan Propo- } \\
\text { sal Kredt Usshs }\end{array}$ & $-3,7236$ & $-1,96$ & 500 & 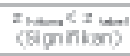 \\
\hline \multirow{2}{*}{ ketorampilan } & \multirow{2}{*}{ U) $t$} & 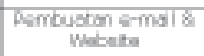 & 21,07700 & 2,2010 & $9 \%$ & 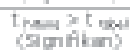 \\
\hline & & $\begin{array}{l}\text { Pombuscan bropo- } \\
\text { sell Kredt Ltuha }\end{array}$ & 25,20080 & 2,1096 & $9 \%$ & 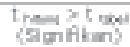 \\
\hline
\end{tabular}

Berdasarkan tabel diatas, dapat disimpulkan hasil penelitian sebagai berikut: Pertama, untuk uji coba tahap I pembelajaran pembuatan e-mail dan web site diperoleh hasil perhitungan sebagai berikut: (a) pada aspek kemampuan pengetahuan terjadi peningkatan rata-rata skor sebesar 6.5 atau 36.1\%. Dengan menggunakan uji t terhadap data pre-test dan posttest diperoleh nilai $\mathrm{t}=7,15298>\mathrm{t}_{\text {tabel }}=2,2010$ yang signifikan pada $a=5 \%$. (b) pada aspek sikap terjadi peningkatan ratarata skor sebesar 59.0 atau 30.1\%. Dengan menggunakan uji 
Wilcoxon Mach Pairs Test terhadap data pre-test dan post-test diperoleh nilai $Z_{\text {_nitung }}=-3,0594<-Z_{\text {tabel }}=-1,96$ yang signifikan pada $a=5 \%$. (c) untuk aspek kemampuan keterampilan terjadi peningkatan rata-rata skor sebesar 23,4 atau $50,6 \%$. Dengan menggunakan uji t terhadap data pre-test dan post-test diperoleh nilai $\mathrm{t}_{\text {_hitung }}=21,07799>\mathrm{t}_{\text {-tabel }}=2,2010$ yang signifikan pada á $=5 \%$.

Kedua, untuk uji coba tahap II pembelajaran pembuatan proposal kredit usaha, diperoleh hasil perhitungan sebagai berikut: (a) pada aspek kemampuan pengetahuan terjadi peningkatan rata-rata skor sebesar 6.0 atau 33,3\%. Dengan menggunakan uji t terhadap data pre-test dan post-test diperoleh nilai __hitung $_{\text {- }}=8,93454>\mathrm{t}_{\text {-tabel }}=2,1098$, yang signifikan pada $a=5 \%$. (b) untuk aspek sikap terjadi peningkatan ratarata skor sebesar 59.8 atau 31.2\%. Dengan menggunakan uji Wilcoxon Mach Pairs Test terhadap data pre-test dan post-test diperoleh nilai $z=-3,7236<-Z_{\text {tabel }}=-1,96$ yang signifikan pada $a=5 \%$. (c) pada aspek kemampuan keterampilan terjadi peningkatan rata-rata skor sebesar 22.5 atau 49,0\%. Dengan menggunakan uji t terhadap data pre-test dan post-test diperoleh nilai $t=25,20989>t$ tabel $=2,1098$ yang signifikan pada $a=5 \%$. Berdasarkan kedua uji coba diatas, dapat disimpulkan bahwa model fasilitasi elajar dapat meningkatkan kemampuan pengetahuan (cognitive), sikap (afektif) dan keterampilan (psychomotor) anggota kelompok pelaku usaha kecil di sentra kerajinan Cibeusi dalam mengembangkan kemandirian usaha produktifnya.

\section{B. Saran}

Memperhatikan temuan hasil analisis data, model temuan penelitian, dan teori-teori yang dijadikan rujukan sebagai landasan operasional dan pembahasan dalam penelitian ini, akhirnya direkomendasikan beberapa hal penting bagi: (1) penerapan model, (2) instansi terkait, dan (3) penelitian lanjutan. 


\section{Saran untuk Penerapan Model}

Dalam penerapan model fasilitasi belajar ini menuntut pihak agen perubahan atau pengelola suatu program pendidikan luar sekolah lainnya untuk mempelajari langkah-langkah praktisnya yang dilandasi alasan-alasan filosofis dan alasan-alasan praktisnya. Sehubungan model ini merupakan model yang berupaya memberdayakan masyarakat dari ketidakmampuan menjadi lebih mampu, maka pengelola pendidikan luar sekolah atau agent perubahan perlu melibatkan anggota kelompok sasaran dalam semua langkah kegiatan pembelajaran mulai proses perencanaan, pengorganisasian, pelaksanaan dan pengevaluasian. Dalam praktek pelibatan anggota kelompok sasaran tersebut, seharusnya fasilitator berpegang kepada konsep andragogik, sehingga mereka tidak diperlakukan sebagai orang awam yang tidak memiliki kemampuan dan pengalaman, tetapi harus diakui bahwa mereka sebagai orang dewasa memiliki pengamalan yang cukup untuk dijadikan sumber belajar potensial. Oleh karena itu sumber belajar atau agen pembaharu harus bertindak sebagai fasilitator mediator dalam pembelajaran.

\section{Saran Untuk Instansi Terkait}

Pihak lain yang direkomendasikan untuk membantu kelompok uaha kecil antara laian: (1) pihak pemerintah, hendaknya berfungsi sebagai regulator, fasilitator, motivator dan stimulator, (2) pihak lembaga bank atau lembaga keuangan lainnya, hendaknya memberikan bimbingan dan penyuluhan kepada pelaku usaha kecil, mempermudah dan mempercepat proses penyaluran kredit, menurunkan tingkat suku bunga kredit serta memberikan kredit tanpa agunan, (3) pihak lembaga swadaya masyarakat, hendaknya berfungsi sebagai lembaga yang dapat memberikan pelatihan/konsultasi tentang cara membuat perencanan usaha, pemasaran dan administrasi perusahaan, serta membantu mencari mitra eksportir. 


\section{DAFTAR BACAAN}

Abdulhak, I., (2001). Komunikasi Pembelajaran: Pendekatan Konvergensi dalam Peningkatan Kualitas dan Efektivitas Pembelajaran. Pidato Pengukuhan Guru Besar.

Borg W.R. and Gall. M.D., (1979). Educational Research: An Introduction (third ed.). New York London: Longman.

Bloom. B, (1956). Taxonomy of Education Objective. New York. Company, Inc.

Botkin, W.J., (1984). No Limit To Learning. New York: Perganmon Press.

Cross., (1986). Adult as Learning. San Fransisco: Josse Publishing. Co.,

Coombs, P., dan Ahmad, M., (1974). Attacking Rural Poverty: How Non Formal Education Can Help. Baltimore: The John Hopkins Press.

Fraenkel, J.R. (1993). How To Design and Evaluate Research in Education. Singapura: McGraw-Hill.

Grove., (2004). Principles of Facilitation (Online). Available: http:// www.grove.com/about/model_facil.html\#model. (2005, July 3)

Havelock, R.G. (1975). The Change Agent's Guide to Innovation in Education. New Jersey: Educational Technology Publication Englewood Cliffs.

Kindervatter, S., (1979). Non Formal Education As an Empowering Process. Amherst. Massachussets: Centre for International Education University of Massachussets.

Knowles, M., (1977). The Modern Practice of Adult Education, Andragogy Versus Pedagogy, Assosiation Press, New York.

Laird, D. (1985). Approaches to training and development, Reading, Mass: Addison Wesley.(Online)Available:http://www.brookes.ac.uk/ services/ocsd/ 4_resource/ 4_resource.html (2004, Agustus 25)

Leighbody, G.B., (1968). Methods of teaching shop and technical subjects. New York: Delmar Publishing

Mitcell Stewart, A,. 1994. Empowering People. Britain: Pitman Puiblishing-Divison of Longman Group UK. Ltd.,

Millan, J.H \& Schumacher, S. (2001). Research in Education: A 
Conceptual Introduction. Horrisonburg: RR. Donnelley \& Son., Inc. Ordonez., (1999). Basic Education for Empowerment of The Poor; Raport of a Regional Study on Literacy as a Tool for Empowerment of the Poor. Bangkok: UNESCO PROAP.

Peraturan Pemerintah Republik Indonesia No. 73 Tahun 1991 tentang Pendidikan Luar Sekolah.

Rogers, (1994b). Adult Learning. Philadelphia: Open University Press. Roger, S., (1994). The Skilled Facilitator. San Francisco: Jossey-Bass Publishing. (Online) Available: http://www. bigg.or.id/PDF/ manual02.pdf. (2004, Agustus 28)

Saepudin, A. (2005). Pengajaran Berpikir: Suatu Konsep Pengembangan Proses Belajar Mengajar. Jakarta: Jurnal Teknodik Pustekom Depdiknas No. 17/IX/Teknodik/Des/2005.

Silberman, (1990). Active Training . Handbook Of Techniques, Design, Case Examples, And Tips. (Online).Available: http:// www.bkkbn.go.id/hqweb/ceria/mb11napza01.html\#1 (2004, July 27)

Schuman, S., (2004). Facilitator Competencies (Online).Available:http:/ /www albany. edu/cpr/gf/resources/FacilitatorCompetencies.html (2004, Agustus 12)

Sudjana, H.D. (2000a). Manajemen Program Pendidikan: untuk Pendidikan Luar Sekolah dan Pengembangan SDM. Bandung; Falah Production.

Tambunan, T., (2003). Usaha Kecil Indonesia: Tinjauan tahun 2002 prospek tahun 2003. Jakarta: PUPUK LP3E-KADIN.

Undang-undang Republik Indonesia No. 9/1995 tentang Usaha Kecil 